\title{
Prophylaxis with $\alpha$-lipoic acid against lipopolysaccharide-induced brain injury in rats
}

\section{Anna Gorąca and Katarzyna Asłanowicz-Antkowiak}

Chair of Experimental and Clinical Physiology, Department of Cardiovascular Physiology, Medical University of Łódź, Łódź, Poland

Received: 2008.02.25, Accepted: 2008.10.09, Published online: 2009.03.31

(C) L. Hirszfeld Institute of Immunology and Experimental Therapy, Wrocław, Poland 2009

\begin{abstract}
Introduction: Lipopolysaccharide (LPS) stimulates the synthesis and release of reactive oxygen species that play an important role in the pathogenesis of tissue injuries. In this study the effect of early administration of the antioxidant $\alpha$-lipoic acid $\left(\alpha\right.$-LA) on brain lipid peroxidation, brain hydrogen peroxide $\left(\mathrm{H}_{2} \mathrm{O}_{2}\right)$ concentration, and brain total sulfhydryl group (-SH group) content was evaluated in rats with endotoxic shock induced by administration of LPS (Escherichia coli 026:B6, 30 $\mathrm{mg} / \mathrm{kg}$ i.v.)

Materials and Methods: Rats were treated intravenously with normal saline or $\alpha$-LA $(60 \mathrm{mg} / \mathrm{kg}) 30 \mathrm{~min}$ after LPS injection. After $5 \mathrm{~h}$ of observation, the animals were killed and their brains were isolated for the measurements.

Results: Injection of LPS alone resulted in the development of shock and oxidative stress, the latter indicated by a significant increase in brain concentrations of thiobarbituric acid-reacting substances (TBARS) and $\mathrm{H}_{2} \mathrm{O}_{2}$ and a decrease in total brain -SH group content. Administration of $\alpha$-LA after the LPS challenge resulted in an increase in total -SH group content and a decrease in TBARS and $\mathrm{H}_{2} \mathrm{O}_{2}$ concentration in the brain tissue compared with the LPS group.

Conclusion: The results indicate that $\alpha$-LA treatment effectively protected the brain tissue against endotoxin-induced oxidative stress. Administration of LA could be a useful adjunct to clinical application in the management of septic shock.

Key words: lipopolysaccharide, alpha-lipoic acid, oxidative stress.

Abbreviations: LPS - lipopolysaccharide, LA - lipoic acid, $\mathrm{H}_{2} \mathrm{O}_{2}$ - hydrogen peroxide, TBARS - thiobarbituric acid reactive substance, TNF- $\alpha$ - tumor necrosis factor $\alpha$, IL - interleukin, ROS - reactive oxygen species, GSH - glutathione, GSSG oxidized glutathione, -SH group - sulfhydryl group, TBA - thiobarbituric acid, TCA - trichloroacetic acid, BHT - butylated hydroxytoluene, HVA - homovanilic acid, PBS - phosphate-buffered saline, EDTA - ethylenediamine tetraacetic acid.
\end{abstract}

Corresponding author: Anna Gorąca, Associate Professor, Chair of Experimental and Clinical Physiology, Department of Cardiovascular Physiology, Mazowiecka 6/8, 92-215 Lódź, Poland, tel./fax: +48 42-6782661, e-mail: agoraca@zdn.am.lodz.pl

\section{INTRODUCTION}

Lipopolysaccharide (endotoxin; LPS) is a major component of the outer membrane of Gram-negative bacteria and is responsible for the initiation of the host response to the microorganisms. The first phagocytic cells that come into contact with the LPS are macrophages and neutrophils. In response to LPS, macrophages secrete proinflammatory cytokines such as tumor necrosis factor (TNF)- $\alpha$, the interleukins IL-6, IL-1 $\beta$, and IL-12 (Kagan et al. 1992; Panigrahi et al. 1996; Rankine et al. 2006), free radicals, and reactive oxygen species (ROS), such as superoxide anion (Minuz et al 2006; Victor et al 2003). An excess of ROS may cause cell death by oxidizing proteins, DNA damage, or lipid peroxidation of cellular membranes (Floyd et al. 2001; Laskin and Pendino 1995). It is well documented that proinflammatory cytokines and ROS contribute to the development of septic shock, multiple organ failure, and death.

Brain tissue is highly susceptible to oxidative injury compared with other tissues (Halliwell 2006). The vulnerability of the brain to oxidative damage is probably due to membrane phospholipids rich in polyunsaturated fatty acids, which are a source of peroxidation, a high consumption of oxygen and a low quantity of enzymes mopping up ROS, and neurons' inability to multiply. As the capacity of the endogenous antioxidative system of brain tissue is limited, antioxidants such as LA could protect neural tissue from being damaged by increased ROS. 
DL-o-lipoic acid (LA, DL-6,8-dithiooctanoic acid) is an endogenous thiol antioxidant that has the potential to quench ROS, regenerate glutathione (GSH), and chelate metals such as iron, copper, mercury, and cadmium, which are known to mediate free-radical damage in biological systems (Akpinar et al. 2007; Applegate et al. 2008; Bilska and Włodek 2005; Savitha et al. 2005; Skibska et al. 2006). As LA is well soluble not only in water, but in fats as well, and is a small molecule (molecular weight: 206), it may easily cross the blood-brain barrier and stabilize it (Cakatay 2006; Roy and Packer 1998; Roy et al. 1997; Schreibelt et al. 2006).

In most of the experiments performed by other authors, LA was administered before oxidative stress was observed. The present study was undertaken to investigate whether LA affects the level of lipid peroxidation, hydrogen peroxide $\left(\mathrm{H}_{2} \mathrm{O}_{2}\right)$ concentration, and the content of sulfhydryl groups (-SH groups) in the brains of endotoxin-pretreated male rats.

\section{MATERIALS AND METHODS}

\section{Chemicals}

Lipopolysaccharide (Escherichia coli LPS 026:B6, lyophilized powder chromatographically purified by gel filtration, protein content $<1 \%$ ), $\alpha$-LA, thiobarbituric acid (TBA), butylated hydroxytoluene (BHT), and sodium acetate trihydrate were purchased from Sigma Chemical Co. (St. Louis, MO, USA). All other reagents were obtained from POCh (Gliwice, Poland) and were of analytical grade. Shortly before use, the LPS was dissolved in sterile pyrogen-free normal saline. $\alpha$-LA was mixed with sterile normal saline in a dark bottle and $\mathrm{NaOH}$ was added until the suspension was dissolved. The $\mathrm{pH}$ was then brought to 7.4 with $\mathrm{HCl}$. TBA solution was prepared by dissolving $0.67 \mathrm{~g}$ of TBA in $100 \mathrm{ml}$ of de-ionized water and then diluted 1:1 with glacial acetic acid. Sterile, de-ionized water (resistance $>18 \mathrm{M} \Omega$-cm, HPLC Water Purification System USF ELGA, England) was used throughout the study.

\section{Animals}

The experiments were performed on 52 adult male Wistar rats weighing 260-300 g. The animals were housed six rats per cage under standard laboratory conditions, with a 12/12 h light-dark cycle (light on at 7:00 a.m.), an ambient temperature of $20 \pm 2^{\circ} \mathrm{C}$, and humidity of $55 \pm 5 \%$. All the animals received a standard laboratory diet and water ad libitum. All the animals were given a one-week acclimation period before the start of the experiment. The experimental procedures followed the guidelines for the care and use of laboratory animals and were approved by the Medical University of Lódź Ethics Committee.

\section{Experimental design}

The animals were randomly divided into five groups. Group I ( $\mathrm{n}=10, \mathrm{NaCl} / \mathrm{NaCl}$ control rats) received $0.2 \mathrm{ml}$ saline twice, $0.5 \mathrm{~h}$ apart. Group II $(\mathrm{n}=10, \mathrm{NaCl} / \mathrm{LA} 60$ group) served as LA controls; the animals received 0.2 $\mathrm{ml}$ saline and were injected $0.5 \mathrm{~h}$ later with a single dose $(60 \mathrm{mg} / \mathrm{kg}$ b.w.) of DL- $\alpha$-LA. Group III $(\mathrm{n}=10$, $\mathrm{NaCl} / \mathrm{LA} 100$ group) received $0.2 \mathrm{ml}$ saline and were injected with a single dose $(100 \mathrm{mg} / \mathrm{kg})$ of DL- $\alpha$-LA 0.5 $\mathrm{h}$ later. Group IV $(\mathrm{n}=12$, with 2 dead animals during the experiment, $\mathrm{NaCl} / \mathrm{LPS}$ group) served as LPS controls; the rats were given $0.2 \mathrm{ml}$ saline and endotoxic shock was induced $0.5 \mathrm{~h}$ later by an injection of $E$. coli LPS at a concentration of $30 \mathrm{mg} / \mathrm{kg}$. Group V $(\mathrm{n}=10$, LPS/LA60 group) received a single dose of LPS $(0.2 \mathrm{ml}$, $30 \mathrm{mg} / \mathrm{kg})$ and a single dose of LA $(60 \mathrm{mg} / \mathrm{kg})$ after 0.5 h. Group VI ( $\mathrm{n}=10, \mathrm{LPS} / \mathrm{LA100}$ group) received a $\sin$ gle dose of LPS $(0.2 \mathrm{ml}, 30 \mathrm{mg} / \mathrm{kg})$ and a single dose of $\mathrm{LA}(100 \mathrm{mg} / \mathrm{kg})$ after $0.5 \mathrm{~h}$.

All agents were injected intravenously into the tail vein between 8:00 and 9:00 a.m.. The rat's body temperature was taken in the rectum with a thermistor thermometer (type PU 319/1, Czechoslovakia) before the first injection and then 1,2,3, and $5 \mathrm{~h}$ later. After $5 \mathrm{~h}$ of observation, the animals were anesthetized with pentobarbital (50 mg/kg i.p.).

\section{Brain homogenates}

The skulls were split on an ice and salt mixture and the whole brain of each rat was extracted, weighed, and homogenized in either $1.15 \% \mathrm{KCl}$ for the assay of TBA reactive substance (TBARS) and $\mathrm{H}_{2} \mathrm{O}_{2}$ concentration or in $6 \%$ trichloroacetic acid (TCA) for determination of the content of free -SH groups.

\section{Determination of lipid peroxidation}

The content of lipid peroxidation products in the brain homogenates was assayed as TBARS. Briefly, $4 \mathrm{ml}$ of $0.25 \%$ hydrochloric acid containing $0.375 \%$ TBA, $15 \% \mathrm{TCA}$, and $0.015 \%$ BHT was added to $2 \mathrm{ml}$ of the brain homogenate. The samples were boiled for $30 \mathrm{~min}$ at $100^{\circ} \mathrm{C}$ in tightly closed tubes. After cooling to $10^{\circ} \mathrm{C}, 2.5$ $\mathrm{ml}$ of butanol was added to each tube and, after intensive shaking, the tubes were centrifuged for $10 \mathrm{~min}(3800 \mathrm{rpm}$, $20^{\circ} \mathrm{C}$ ). TBARS in the butanol layer were measured spectrofluorometrically using a Perkin Elmer LS-50 Luminescence Spectrometer (Norwalk, CT, USA). Excitation was set at $515 \mathrm{~nm}$ and emission was measured at $546 \mathrm{~nm}$. The readings were converted into $\mu \mathrm{M}$ by the regression equation

$$
\mathrm{Y}=0.39 \times\left(\mathrm{X}-\mathrm{X}_{\mathrm{o}}\right)-1.32
$$

where $\mathrm{Y}-\mu \mathrm{mol} / \mathrm{l}$ TBARS and $\mathrm{X}$ and $\mathrm{X}_{\mathrm{o}}$ the fluorescence intensities of the sample and control, respectively, in arbitrary units (arbitrary units, AU). The regression equation was prepared from three series of calibration experiments 
with six increasing concentrations of tetramethoxypropane as a standard of TBARS $(0.01-50 \mu \mathrm{M})$. A mixture of $2 \mathrm{ml}$ of $1.15 \%$ potassium chloride and $4 \mathrm{ml}$ of $0.25 \mathrm{~N}$ hydrochloric acid was used as a control. Finally, the results were calculated for $50 \mathrm{mg}$ of brain tissue.

\section{Determination of $\mathrm{H}_{2} \mathrm{O}_{2}$}

$\mathrm{H}_{2} \mathrm{O}_{2}$ generation in the brain homogenates was determined according to the Ruch et al. method (Ruch et al. 1983) with some modifications. Briefly, a $10-\mu \mathrm{l}$ aliquot of tissue homogenate was mixed with (i) $90 \mu \mathrm{l}$ of phosphate-buffered saline (PBS, pH 7) and $100 \mu \mathrm{l}$ of horseradish peroxidase $(1 \mathrm{U} / \mathrm{ml})$ containing $400 \mu \mathrm{mol}$ homovanilic acid (HRP+HVA assay) or (ii) $90 \mu \mathrm{l}$ of PBS and $100 \mu \mathrm{l}$ of $1 \mathrm{U} / \mathrm{ml}$ horseradish peroxidase only (HRP assay). Both homogenates were incubated for 60 $\min$ at $37^{\circ} \mathrm{C}$. Then $300 \mu \mathrm{l}$ of PBS and $125 \mu$ of $0.1 \mathrm{M}$ glicyne- $\mathrm{NaOH}$ buffer (pH 12.0) with $25 \mathrm{mM}$ EDTA were added to each homogenate sample. Excitation was set at $312 \mathrm{~nm}$ and emission was measured at $420 \mathrm{~nm}$ (Perkin Elmer Luminescence Spectrometer, Beaconsfield, UK). The readings were converted into $\mathrm{H}_{2} \mathrm{O}_{2}$ concentration using the regression equation

$$
\mathrm{Y}=0.012 \times \mathrm{X}-0.0007
$$

where $\mathrm{Y}$ is the concentration of $\mathrm{H}_{2} \mathrm{O}_{2}$ in the homogenate $(\mu \mathrm{M})$ and $\mathrm{X}$ the intensity of light emission at $420 \mathrm{~nm}$ for the HRP+HVA assay reduced by the HRP assay emission (AU). The regression equation was prepared from three series of calibration experiments with 10 increasing $\mathrm{H}_{2} \mathrm{O}_{2}$ concentrations (range: 10-1000 $\mu \mathrm{M}$ ). The lower limit of $\mathrm{H}_{2} \mathrm{O}_{2}$ detection was set $0.1 \mathrm{nM}$, with intra-assay variability not exceeding $2 \%$.

\section{Measurement of the total-SH group content in brain homogenates}

The -SH group content in the tissue homogenates was determined by the 2.2-dithiobisnitrobenzoic acid (DTNB) assay described by Ellman (Ellman 1970).
Briefly, $50 \mathrm{mg}$ of the organ sample was thawed and homogenized with $6 \%$ TCA in a 1:20 volume proportion at $0^{\circ} \mathrm{C}$. Then the homogenate was centrifuged for $20 \mathrm{~min}$ $\left(10,000 \times \mathrm{g}, 4^{\circ} \mathrm{C}\right)$. The volume of $0.5 \mathrm{ml}$ of the supernatant was mixed with $0.5 \mathrm{ml}$ of $0.3 \mathrm{M} \mathrm{Na}_{2} \mathrm{HPO}_{4}$ and $0.5 \mathrm{ml}$ of $0.04 \%$ Ellman reagent (DTNB) freshly dissolved in $10 \%$ sodium citrate water solution. All the reagents added were previously cooled to $0^{\circ} \mathrm{C}$. The absorbance of the obtained solution was measured at $412 \mathrm{~nm}$ using a Pharmacia LKB-Ultrospect III spectrophotometer. The readings were converted into $-\mathrm{SH}$ group content $(\mu \mathrm{M})$ by the regression equation

$$
Y=-0.2998+241.954 \times X
$$

where $\mathrm{Y}$ is the free $-\mathrm{SH}$ group content $(\mu \mathrm{M})$ and $\mathrm{X}$ the intensity of light emission at $420 \mathrm{~nm}$ (AU). The regression equation was prepared on the basis of three series of calibration experiments in which increasing concentrations of GSH (2-200 $\mu \mathrm{mol} / \mathrm{l})$ were used. The control assay was carried out with a solution of $0.5 \mathrm{ml}$ of $6 \%$ TCA, $0.5 \mathrm{ml}$ of $0.3 \mathrm{M}$ $\mathrm{Na}_{2} \mathrm{HPO}_{4}$ - sodium phosphate, and $0.5 \mathrm{ml}$ of $0.04 \%$ DTNB.

\section{Statistical analysis}

Data are presented as the mean \pm SE from 10 animals in each group. Statistical significance was evaluated using the ANOVA test followed by Duncan's multiple range test as a post hoc test. Differences were considered significant if $\mathrm{p} \leq 0.05$.

\section{RESULTS}

\section{Body temperature and general behavior}

In the control group there was no change in body temperature throughout the experiment $\left(33.2 \pm 0.1^{\circ} \mathrm{C}\right)$. Similarly, infusion of $\alpha$-LA had no effect on body temperature. Injection of LPS resulted in a body temperature decline of about $2^{\circ} \mathrm{C}$ compared with the saline and $\mathrm{Na} / \mathrm{LA}$ groups $(\mathrm{p}<0.001)$. Some decrease in body temperature was observed in the LPS/LA60 group, but after $5 \mathrm{~h}$ of

Table 1. The effect of lipoic acid on LPS-induced changes in the body temperature in rats

\begin{tabular}{lccccc}
\hline $\begin{array}{l}\text { Temperature/ } \\
\text { Group } \\
\text { of animals }\end{array}$ & Before & $1 \mathrm{~h}$ & $2 \mathrm{~h}$ & $3 \mathrm{~h}$ & $5 \mathrm{~h}$ \\
\hline $\mathrm{NaCl} / \mathrm{NaCl}$ & $33.2 \pm 0.20$ & $33.2 \pm 0.20$ & $33.2 \pm 0.20$ & $33.2 \pm 0.20$ & $33.2 \pm 0.20$ \\
$\mathrm{NaCl} / \mathrm{LA} 60$ & $33.7 \pm 0.20$ & $33.8 \pm 0.25$ & $33.7 \pm 0.30$ & $33.8 \pm 0.20$ & $33.5 \pm 0.20$ \\
$\mathrm{NaCl} / \mathrm{LA} 100$ & $33.5 \pm 0.20$ & $33.6 \pm 0.20$ & $33.4 \pm 0.23$ & $33.3 \pm 0.20$ & $33.3 \pm 0.15$ \\
$\mathrm{NaCl} / \mathrm{LPS}$ & $33.3 \pm 0.13$ & $32.0 \pm 0.19^{\mathrm{b}}$ & $31.6 \pm 0.20^{\mathrm{b}}$ & $31.5 \pm 0.20^{\mathrm{b}}$ & $31.5 \pm 0.20^{\mathrm{b}}$ \\
$\mathrm{LPS} / \mathrm{LA} 60$ & $33.3 \pm 0.15$ & $33.0 \pm 0.29$ & $32.2 \pm 0.30^{\mathrm{a}}$ & $32.2 \pm 0.40^{\mathrm{a}}$ & $32.6 \pm 0.30$ \\
LPS/LA100 & $33.3 \pm 0.20$ & $33.2 \pm 0.20$ & $33.2 \pm 0.20$ & $33.0 \pm 0.29$ & $33.1 \pm 0.22$ \\
\hline
\end{tabular}

LPS (30 mg/kg, i.v.) or $0.2 \mathrm{ml}$ saline were administered into the tail vein and the rats were injected $0.5 \mathrm{~h}$ later with LA (60 or 100 $\mathrm{mg} / \mathrm{kg}$, i.v.). Body temperature was measured in the rectum before and $1,2,3$, and $5 \mathrm{~h}$ after injections. Mean $\pm \mathrm{SE}$, ${ }^{\mathrm{a}} \mathrm{p}<0.001$, ${ }^{\mathrm{b}} \mathrm{p}<0.05$ vs. baseline temperature. 
observation the body temperature rose to $32.6 \pm 0.3^{\circ} \mathrm{C}$ (Table 1). In the NaCl/LA100 group, no decrease in body temperature was observed. Animals challenged with LPS alone displayed reduced motor activity and adopted a hunched posture. The changes in animal behavior were visible within $1 \mathrm{~h}$ after LPS injection. In contrast, the behavior of the animals of the LPS/LA60 and LPS/LA100 groups was similar to that of the control group. Mortality in the $\mathrm{NaCl} / \mathrm{LPS}$ group was about $17 \%$. No animals died in the control, $\mathrm{NaCl} / \mathrm{LA} 60, \mathrm{NaCl} / \mathrm{LA} 100$, and LPS/LA groups.

\section{Changes in brain lipid peroxidation levels}

The TBARS level in the brain homogenates after LPS administration (group IV) was 3.3-fold higher than in the control group $(\mathrm{p}<0.001, \mathrm{n}=10)$. The level of TBARS in the $\mathrm{NaCl} / \mathrm{LA} 60$ group slightly decreased $(\mathrm{p}<0.05)$ compared with the control group. LA 60 $\mathrm{mg} / \mathrm{kg}$ administered after LPS challenge (group V) significantly suppressed the extent of lipid peroxidation in the brain homogenates compared with the $\mathrm{NaCl} / \mathrm{LPS}$ group $(1.49 \pm 0.2$ vs. $4.37 \pm 0.37 \mu \mathrm{M}, \mathrm{p}<0.001, \mathrm{n}=10)$. Similar results were obtained with a 1.5 -fold higher dose of LA (Table 2).

\section{Changes in $\mathrm{H}_{2} \mathrm{O}_{2}$ concentration}

The concentration of $\mathrm{H}_{2} \mathrm{O}_{2}$ in brain homogenate was significantly higher in the animals treatment with LPS than in the controls $(0.173 \pm 0.013$ vs. $0.037 \pm 0.006 \mu \mathrm{M}$, $\mathrm{p}<0.001, \mathrm{n}=10)$. The administration of LA $(60 \mathrm{mg} / \mathrm{kg}$ b.w.) after LPS challenge significantly reduced $\mathrm{H}_{2} \mathrm{O}_{2}$ concentration in the brain homogenates compared with the LPS group $(0.113 \pm 0.014$ vs. $0.173 \pm 0.013 \mu \mathrm{M}, \mathrm{p}<0.01$, $\mathrm{n}=10$ ). LA at a dose of $100 \mathrm{mg} / \mathrm{kg}$ b.w. reduced $\mathrm{H}_{2} \mathrm{O}_{2}$ concentration in the brain homogenates in the same range of values as LA at a dose of $60 \mathrm{mg} / \mathrm{kg}$ (Table 2).

\section{Content of total -SH groups in the brain}

Rats treated with LPS (group IV) had significantly $(\mathrm{p}<0.01)$ lower $-\mathrm{SH}$ groups levels than rats treated with LA (groups II and III). Administration of LA $(60 \mathrm{mg} / \mathrm{kg}$ b.w.) after LPS challenge significantly increased the content of -SH groups in the brain homogenates compared with the $\mathrm{NaCl} / \mathrm{LPS}$ group $(5.53 \pm 0.33$ vs. $4.06 \pm 0.28 \mu \mathrm{M}, \mathrm{p}<0.01, \mathrm{n}=10)$. Similar results were obtained with the higher dose of LA $(100 \mathrm{mg} / \mathrm{kg}$ b.w.; Table 2).

\section{DISCUSSION}

These data show that intravenous administration of LPS causes oxidative brain injury which is manifested by a significant increase in TBARS and $\mathrm{H}_{2} \mathrm{O}_{2}$ concentration and a decrease in the concentration of - $\mathrm{SH}$ groups in brain homogenates. The increase in lipid peroxidation in this study is a result of increased ROS production, which in turn leads to excessive peroxidation of polyunsaturated fatty acids, causing neuron damage (Halliwell 2006; Halliwel and Gutteridge 1997; Muthuswamy et al. 2006). It was previously reported that LPS, a potent inducer of inflammation and activator of macrophages, produces an abundance of ROS in microglia cells present in the brain (Halliwell 2006). The neurotoxic effects of LPS on brain neurons are mediated by the activation of microglial cells, IL- $1 \beta$, and caspase-11 (Arai et al. 2004). Moreover, the systemic administration of LPS (experimental model of sepsis) causes a release of glutamate, aspartate, and taurine in the central nervous system which in excess cause disturbances in calcium homeostasis, leading to the production of free radicals (Lin et al. 1999; Packer et al. 1997).

The increased formation of ROS in our study was indicated by the increased level of $\mathrm{H}_{2} \mathrm{O}_{2}$ in the brains of the LPS-challenged rats. $\mathrm{H}_{2} \mathrm{O}_{2}$ is an important component of the cascade of events during which ROS are produced (Halliwell 2006; Panigrahi et al. 1996) and is one of the most stable toxic oxygen metabolites. It is also volatile and, due to its lack of charge, easily crosses cell membranes by simple diffusion. This allows the promotion of radical reactions at a great distance from its origin. Catalase and GSH peroxidase are basic enzymes regulating intracellular $\mathrm{H}_{2} \mathrm{O}_{2}$ concentration. In the brain, catalase activity is low and the antioxidant enzyme superoxide dismutase is localized mainly in neurons (Delacourte et al. 1988), while GSH peroxidase and

Table 2. The influence of administration of LA on oxidative stress parameters in brain homogenates of rats subjected to LPSinduced shock

\begin{tabular}{|c|c|c|c|c|c|c|}
\hline Parameter & Saline & LA60 & LA100 & LPS & LPS+LA60 & LPS+LA100 \\
\hline TBARS $(\mu \mathrm{M})$ & $1.320 \pm 0.022$ & $0.870 \pm 0.010^{\mathrm{b}}$ & $0.860 \pm 0.040^{\mathrm{b}}$ & $4.370 \pm 0.370^{\mathrm{a}, \mathrm{b}}$ & $1.490 \pm 0.200^{\mathrm{a}, \mathrm{d}}$ & $1.470 \pm 0.028^{\mathrm{a}, \mathrm{c}, \mathrm{d}}$ \\
\hline $\mathrm{H}_{2} \mathrm{O}_{2}(\mu \mathrm{M})$ & $0.037 \pm 0.005$ & $0.039 \pm 0.006$ & $0.036 \pm 0.004$ & $0.173 \pm 0.013^{\mathrm{a}, \mathrm{b}}$ & $0.113 \pm 0.014^{\mathrm{b}, \mathrm{e}}$ & $0.111 \pm 0.013^{b, c, e}$ \\
\hline $\begin{array}{l}\text { Free-SH } \\
\text { groups }(\mu \mathrm{M})\end{array}$ & $5.310 \pm 0.270$ & $5.510 \pm 0.300$ & $5.610 \pm 0.270$ & $4.060 \pm 0.280^{\mathrm{a}, \mathrm{c}}$ & $5.530 \pm 0.330^{\mathrm{e}}$ & $5.550 \pm 0.290^{\mathrm{e}}$ \\
\hline
\end{tabular}

Two doses of LA were used: 60 and $100 \mathrm{mg} / \mathrm{kg}$ b.w. Mean \pm SE.

All administrations were performed intravenously between 8:00 and 9:00 a.m. ${ }^{\mathrm{a} p}<0.001$ vs. LA60 or LA100, ${ }^{\mathrm{b}} \mathrm{p}<0.001$ vs. saline, ${ }^{c} \mathrm{p}<0.01$ vs. saline, ${ }^{\mathrm{d}} \mathrm{p}<0.001$ vs. LPS, ${ }^{\mathrm{e}} \mathrm{p}<0.01$ vs. LPS.

Abbreviations: LPS - lipopolysaccharide, LA60 - lipoic acid 60 mg/kg body weight, LA100 - lipoic acid 100 mg/kg; TBARS thiobarbituric acid-reactive substances. 
GSH are mainly in astrocytes (Benzi and Moretti 1995). A deficit of these enzymes and their localization in the brain suggest that neural tissue may be especially susceptible to hydroxyl radicals (Packer et al. 1997). In case of an inadequate level of enzymes able to degrade $\mathrm{H}_{2} \mathrm{O}_{2}$, more $\mathrm{H}_{2} \mathrm{O}_{2}$ can be converted to toxic hydroxyl radical that could then contribute to oxidative stress.

In this study, the decrease in the content of - $\mathrm{SH}$ groups in the LPS-treated rats may be a result of decreased activity of GSH reductase (Rankine et al. 2006) and transferase or increased activity of GSH peroxidase (Malmezat et al. 2000). A decreased concentration of tissue GSH and an increase in GSSG concentration during the initial phase of septic shock was observed by Tsiotou et al. (Tsiotou et al. 2005).

The present study also showed that LA at a dose of $60 \mathrm{mg} / \mathrm{kg}$ is highly effective in reducing free radicals and lipid peroxidation in the brains of septic rats. Administration of LA $0.5 \mathrm{~h}$ after i.v. LPS injection caused significant decreases in both TBARS and $\mathrm{H}_{2} \mathrm{O}_{2}$ concentrations in brain homogenates. However, more than a 1.5-fold increase in the dose of LA did not cause a further reduction in the scale of oxidative brain damage. Moreover, LA administration also resulted in improved survival rate and less advanced hypothermic reaction of septic rats compared with untreated animals, which is in agreement with other reports (Riedel et al. 2003). Panigrahi et al. (Panigrahi et al. 1996) indicated that the administration of LA to animals subjected to ischemia-reperfusion (e.g. by occlusion of a cerebral artery) alleviated the effects of reperfusion, lowered the level of ROS in the brain cells, reduced an extent of damage, and prolonged the survival time of the animals compared with a control group.

It was also demonstrated in the present study that early administration of LA after LPS challenge significantly increased the brain SH group content. An increase in - $\mathrm{SH}$ group concentration after administration of both LA doses (60 and $100 \mathrm{mg} / \mathrm{kg}$ b.w.) may indicate an enhanced synthesis of proteins containing $\mathrm{SH}$ groups or the synthesis of GSH. It has been demonstrated that LA increased the de novo synthesis of cellular GSH by improving cysteine utilization (Han et al. 1997). An increase in GSH concentration may lead to a higher activity of enzymes involved in GSH synthesis and a reduction in GSH as well (Malmezat et al. 2000). $\mathrm{GSH}$ maintains the reduced state of -SH groups required for the proper function of different types of proteins. For this reason, maintaining intracellular GSH at an appropriate level is essential for protecting neurons against oxidative stress. In in vivo and in vitro studies it has been shown that the administration of LA increased the intracellular GSH level by 30-70\% (Han et al. 1995). Another action of $\alpha$-LA in brain tissue and also in the other tissues is connected with its inhibition of NF- $\kappa \mathrm{B}$ and AP-1 (a dimer of c-fos and c-jun proteins) activity (Minuz et al 2006). Furthermore, LA contributes to other antioxidant systems by enhancing the effects of coenzyme Q10 and GSH (Savitha et al. 2005) and also by regenerating other antioxidants, such as vitamins C and E (Kagan et al. 1992). All these effects of LA in LPS-induced sepsis are in accordance with the findings of LA's antioxidant properties. Moreover, this antioxidant can also inhibit acute inflammatory response in vitro and in vivo by activating the PI3/Akt pathway (Zhang et al. 2007).

In conclusion, this study suggests that LA limits damage to nerve tissue and protects it from being exposed to oxidizing stress even if this antioxidant is administered $0.5 \mathrm{~h}$ after LPS challenge. The effectiveness of LA's protective action against endotoxic brain damage indicated by our experiments could encourage the clinical use of this compound as a treatment for endotoxemia.

Acknowledgment: We would like to express our gratitude to Mrs. Anna Kliszko and Mrs. Zdzisława Sędzińska for technical assistance during the experiments. The study was supported by grant no. 503-1079-1 from the Medical University of Łódź.

\section{REFERENCES}

Akpinar D, Yargicoglu P, Derin N et al (2007) The effect of lipoic acid on lipid peroxidation and visual evoked potentials (VEPs) in rats exposed to chronic restraint stress. Int J Neurosci 117:1691-1706

Applegate MA, Humphries KM, Szweda LI (2008) Reversible inhibition of alpha-ketoglutarate dehydrogenase by hydrogen peroxide: glutathionylation and protection of lipoic acid. Biochemistry 47:473-478

Arai H, Furuya T, Yasuda T et al (2004) Neurotoxic effects of lipopolysaccharide on nigral dopaminergic neurons are mediated by microglial activation, interleukin 1-beta, and expression of caspase-11 in mice. J Biol Chem 279:51647-51653

Benzi G, Moretti A (1995) Age- and peroxidative stress-related modifications of the cerebral enzymatic activities linked to mitochondria and the glutathione system. Free Radic Biol Med 19:77-101

Bilska A, Włodek L (2005) Lipoic acid - the drug of the future? Pharmacol Rep 57:570-577

Cakatay U (2006) Pro-oxidant actions of alpha-lipoic acid and dihydrolipoic acid. Med Hypotheses 66:110-117

Delacourte A, Defossez A, Ceballos I et al (1988) Preferential localization of copper zinc superoxide dismutase in the vulnerable cortical neurons in Alzheimer's disease. Neurosci. Lett 92:247-253

Ellman GL (1970) SH groups determination in biological fluids. Anal Biochem 46:237

Floyd RA, West M, Hensley K (2001) Oxidative biochemical markers; clue to understanding aging in long-lived species. Exp Gerontol 36:619-640

Halliwell B (2006) Oxidative stress and neurodegeneration: where are we now? J Neurochem 97:1634-1658

Halliwel B, Gutteridge JM (1997) Lipid peroxidation in brain 
homogenates: the role of iron and hydroxyl radicals. J Neurochem 69:1330-1331

Han D, Handelman G, Marcocci L et al (1997) Lipoic acid increases de novo synthesis of cellular glutathione by improving cysteine utilization. Biofactors 6:321-338

Han D, Tritschler HJ, Packer L (1995) Alpha-lipoic acid increases intracellular glutathione in a human T-lymphocyte Jurkat cell line. Biochem Biophys Res Commun 207:258-264

Kagan VE, Shvedova A, Serbinova E et al (1992) Dihydrolipoic acid - a universal antioxidant both in the membrane and in the aqueous phase. Reduction of peroxyl, ascorbyl and chromanoxydl radicals. Biochem Pharmacol 44:1637-1649

Laskin DL, Pendino KJ (1995) Macrophages and inflammatory mediators in tissue injury. Annu Rev Pharmacol Toxicol 35:655-677

Lin HC, Wan FJ, Kang BH et al (1999) Systemic administration of lipopolysaccharide induces release of nitric oxide and glutamate and c-fos expression in the nucleus tractus solitarii of rats. Hypertension 33:1218-1224

Malmezat T, Breuille D, Capitan P et al (2000) Glutathione turnover is increased during the acute phase of sepsis in rats. $\mathrm{J}$ Nutr 130:1239-1246

Minuz P, Fava C, Lechi A (2006) Lipid peroxidation, isoprostanes and vascular damage. Pharmacol Rep Suppl 58:57-68

Muthuswamy AD, Vedagiri K, Ganesan M et al (2006): Oxidative stress-mediated macromolecular damage and dwindle in antioxidant status in aged rat brain regions: role of L-carnitine and DL-alpha-lipoic acid. Clin Chim Acta 368:84-92

Packer L, Tritschler HJ, Wessel K (1997) Neuroprotection by the metabolic antioxidant alpha-lipoic acid. Free Radic Biol Med 22:359-378

Panigrahi M, Sadguna Y, Shivakumar BR et al (1996) Alpha-lipoic acid protects against reperfusion injury following cerebral ischemia in rats. Brain Res 717:184-188

Rankine EL, Hughes PM, Botham MS et al (2006) Brain cytokine synthesis induced by an intraparenchymal injection of LPS is reduced in MCP-1-deficient mice prior to leucocyte recruitment. Eur J Neurosci 24:77-86
Riedel W, Lang U, Oetjen U et al (2003) Inhibition of oxygen radical formation by methylene blue, aspirin, or alpha-lipoic acid, prevents bacterial-lipopolysaccharide-induced fever. Mol Cell Biochem 247:83-94

Roy S, Packer L (1998) Redox regulation of cell functions by alpha-lipoate: biochemical and molecular aspects. Biofactors 8:17-21

Roy S, Sen CK, Tritschler HJ et al (1997) Modulation of cellular reducing equivalent homeostasis by alpha-lipoic acid. Mechanisms and implications for diabetes and ischemic injury. Biochem Pharmacol 53:393-399

Ruch W, Cooper PH, Baggiolini M (1983) Assay of H202 production by macrophages and neurotrophils with homovanilic acid and horse-radish peroxidase. J Immunol Methods 63:347-357

Savitha S, Tamilselvan J, Anusuyadevi M et al (2005) Oxidative stress on mitochondrial antioxidant defense system in the aging process. Role of DL-alpha-lipoic acid and L-carnitine. Clin Chim Acta 355:173-180

Schreibelt G, Musters RJ, Reijerkerk A et al (2006) Lipoic acid affects cellular migration into the central nervous system and stabilizes blood-brain barrier integrity. J Immunol 177:2630-2637

Skibska B, Józefowicz-Okonkwo G, Gorąca A (2006) Protective effects of early administration of alpha-lipoic acid against lipopolysaccharide-induced plasma lipid peroxidation. Pharmacol Rep 58:399-404

Tsiotou AG, Sakorafas GH, Anagnostopoulos G et al (2005) Septic shock; current pathogenetic concept from a clinical perspective. Med Sci Monit 11:RA76-85

Victor VM, De La Fuente M (2003) Changes in the superoxide production and other macrophage functions could be related with the mortality of mice with endotoxin-induced oxidative stress. Physiol Res 52:101-110

Zhang W, Wei H, Hagen T et al (2007) Alpha-lipoic acid attenuates LPS-induced inflammatory responses by activating the Phosphoinositide 3-kinase/Akt signaling pathway. Proc Natl Acad Sci USA 104:4077-4082 